\title{
Analisis MRC untuk karakterisasi akuifer karst di Mataair Mudal, Kabupaten Kuloprogo
}

\author{
Afid Nurkholis, Tjahyo Nugroho Adji, Eko Haryono, Ahmad Cahyadi, Wisnu Agung Waskito, Hamzah \\ Fathoni, Ikhwan Arbi Kurniawan, Romza Fauzan Agniy, Aji Dwi Pratama, Dicky Satria, Hendi \\ Fatchurrohman dan Igor Yoga Bahtiar
}

Karst Research Group, Faculty of Geography, Universitas Gadjah Mada, Indonesia.

Email Koresponden : afidnurkholis@gmail.com

Direvisi: 2019-01-03. Diterima: 2019- 08-22

C2019 Fakultas Geografi UGM dan Ikatan Geograf Indonesia (IGI)

\begin{abstract}
Abstrak Akuifer karst memiliki triple porosity yang membuat karakterisasinya sulit dilakukan. Tujuan dari penelitian ini adalah menganalisis komponen hidrograf banjir dan membuat Master Recession Curve (MRC) pada akuifer karst yang mengimbuh Mataair Mudal. Data yang digunakan adalah debit aliran dan curah hujan yang tercatat setiap 30 menit pada November 2017 hingga Mei 2018 (6 bulan). Hasil penelitian menunjukkan bahwa Mataair Mudal memiliki complex discharge regime dengan derajat karstifikasi pada kelas 5,5. Analisis komponen hidrograf banjir menguatkan hasil perhitungan derajat karstifikasi. Waktu menuju puncak banjir $\left(\mathrm{T}_{\text {lag }}\right)$ yang tergolong cepat $(2,5$ jam) menunjukkan telah adanya aliran conduit. Perhitungan waktu menuju aliran dasar $\left(\mathrm{T}_{\mathrm{b}}\right)$ baik secara manual (hidrograf banjir) maupun automatis (MRC) memiliki rerata sekitar 40 jam yang mencerminkan bahwa akuifer karst yang mengimbunya masih baik dalam menyimpan airtanah. Secara keseluruhan, akuifer karst di Mataair Mudal masih didominasi oleh retakan bertipe diffuse, meskipun sudah memiliki retakan bertipe conduit yang cukup berkembang.
\end{abstract}

Kata kunci : akuifer karst, derajat karstifikasi, hidrograf banjir, master recession curve, Mataair Mudal

Abstract The objective of this research was to analyze the nature of the flood hydrograph components and create a Master Recession Curve $(M R C)$ to estimate the degree of karstification in Mudal Spring. Discharge and rainfall data were recorded every 30 minutes at time intervals between November 2017 and May 2018. The results show that Mudal Spring has a complex discharge regime with a karstification degree in the class of 5.5. Meanwhile, the time to peak flood $\left(T_{\text {lag }}\right)$ which is relatively fast (2.5 hours) shows the existence of conduit flow in the flood event. Calculation of time to baseflow $\left(T_{b}\right)$ has an average of 40 hours which reflects that the karst aquifer was still good in storing groundwater. Overall, karst aquifers in Mudal Spring are still dominated by diffuse type voids, although they already have conduit type voids that are quite developed.

Keywords: karst aquifer, karstification degrees, flood hydrograph, Master Recession Curve, Mudal Spring

\section{PENDAHULUAN}

Karakterisasi akuifer karst dikenal sulit dilakukan karena adanya sifat triple-porosity. Analisis hidrograf aliran pada outlet sistem karst atau mataair merupakan metode yang umum digunakan untuk melakukan karakterisasi akuifer karst (Ford dan Williams, 1989). Tinjauan mengenai beberapa metode untuk analisis hidrograf aliran pada outlet sistem karst atau mataair telah dilakukan oleh Jeannin dan Sauter (1998), yang mencakup analisis kurva resesi, deret waktu, dan perhitungan durasi aliran. Perhitungan konstanta resesi merupakan metode yang sederhana, namun dapat mencerminkan karakteristik akuifer karst dalam melepaskan alirannya dan secara tidak langsung dapat mengetahui tingkat perkembangan pelorongannya (Bonacci, 1993).
Penggunakan konstanta resesi pada bidang hidrologi telah banyak mengalami perkembangan. Perhitungan konstanta resesi secara manual, yaitu menggunakan cara grafis, pertama kali dilakukan oleh Barnes (1939). Penelitian tersebut memisahkan kurva resesi menjadi tiga komponen aliran, yaitu overlandflow, interflow, dan baseflow. Konsep tersebut selanjutnya digunakan oleh Haryono dkk (2016); Adji dan Bahtiar (2016); Adji dkk (2017.a); Adji dkk (2017.b); dan Nurkholis dkk (2017) untuk menghitung konstanta resesi aliran conduit, fissure, dan diffuse pada akuifer karst. Penelitian-penelitian tersebut meggunakan konsep single recession curve dengan persamaan simple exponential form (1) sebagaimana telah dijelaskan oleh 


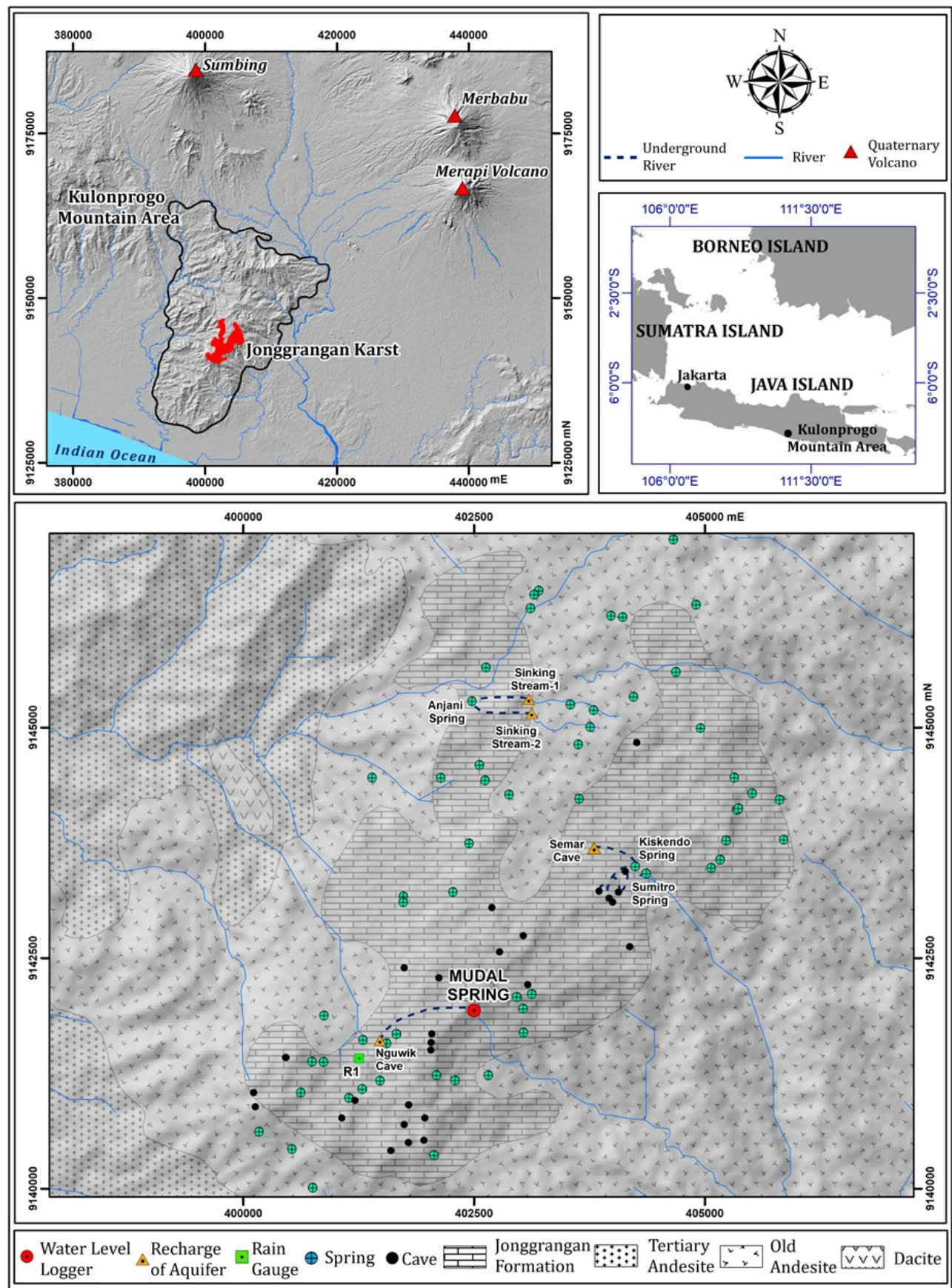

Gambar 1. Lokasi kajian
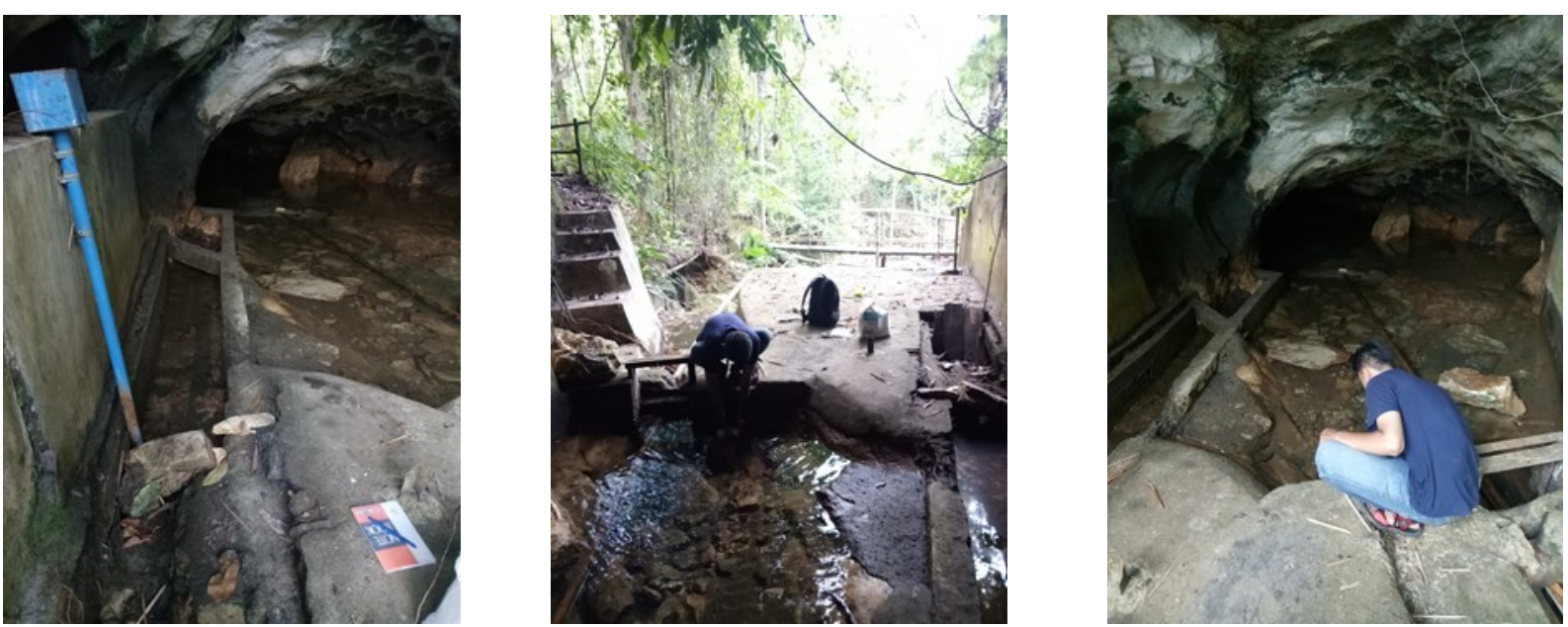

Gambar 2. Logger tinggi muka air (kiri) dan situasi di Mataair Mudal (tengah dan kanan) 
Maillet (1905). Selain itu, Tallaksen (1995) juga mempunyai beberapa persamaaan untuk menghitung recession curve pada sebuah hidrograf aliran.

Penggunaan single recession curve memiliki kekurangan yaitu berupa bervariasinya kurva resesi pada setiap kejadian banjir. Oleh karena itu, pembuatan Master Recession Curve (MRC) yang merupakan penggabungan dari beberapa single recession curve dapat dilakukan. Secara umum, MRC dapat dibuat dengan metode matching strip (Snyder, 1939) atau metode korelasi (Langbein, 1938). Nathan dan McMahon (1990) melakukan penelitian yang menunjukkan bahwa metode matching strip lebih akurat dibandingkan metode korelasi. Arnold dkk (1995) telah membuat MRC secara otomatis dengan komputasi digital yang menunjukkan bahwa hasil perhitungan metode komputasi memiliki tingkat kepercayaan sebesar $74 \%$. Sementara itu, penelitian oleh Berhail dkk (2012) menunjukkan bahwa single recession curve dan MRC sama baiknya ketika digunakan untuk mengidentifikasi karakteristik aliran pada suatu kurva resesi.

Salah satu aplikasi MRC adalah untuk mengetahui derajat karstifikasi suatu akuifer, sebagaimana yang pertama kali diperkenalkan oleh Kullman (2000). Selanjutnya, Malik (2007) telah memodifikasi klasifikasi tersebut untuk digunakan dalam analisis sensitivitas airtanah karst terhadap polutan. Malik dan Vojtkova (2010) juga menggunakan MRC untuk menghitung derajat karstifikasi akuifer karst untuk menganalisis daerah tangkapan air dari dua mataair yang berdekatan. Di Indonesia penerapan perhitungan derajat karstifkasi telah dilakukan oleh Fatchrurohman (2017) dan Fatchrurohman dkk (2018) di karst Gunungsewu, Kabupaten Gunungkidul serta Mujib (2015) di Karst Rengel Selatan, Kabupaten Tuban. Sementara itu, Nurkholis dkk (2019) dan Kurniawan dkk (2019) menggunakan MRC yang dikombinasikan dengan time series analysis untuk melakukan karakterisasi akuifer karst yang lebih mendetail.

Penelitian ini dilakukan di Mataair Mudal, Desa Jatimulyo, Kecamatan Girimulyo, Kabupaten Kulonprogo yang merupakan bagian dari Kawasan Karst Jonggrangan (Gambar 1). Mataair Mudal pada dasarnya adalah sungai bawah tanah yang muncul sebagai sungai resurgence. Saat ini, Mataair Mudal (Gambar 2) telah dikembangkan sebagai ekowisata dengan daya tarik berupa kolam pemandian, taman bermain, dan tempat berkemah (Sari, 2017). Selain itu, Mataair Mudal juga digunakan sebagai sumber air bersih untuk warga sekitar. Mengingat besarnya manfaat Mataair Mudal seperti yang telah dijelaskan di atas, maka penelitian terkait karakterisasi sifat kondisi hidrologi karst penting di mataair ini perlu dilakukan. Secara khusus, penelitian ini bertujuan untuk menganalisis sifat dari komponenkomponen hidrograf banjir, membuat Master Recession Curve (MRC) yang selanjutnya digunakan untuk memperkirakan derajat karstifikasi pada akuifer karst yang mengimbuh Mataair Mudal.

\section{METODE PENELITIAN}

Data tinggi muka air di Mataair Mudal dicatat dari tanggal 7 November 2017 hingga 16 Mei 2018 dengan interval waktu pencatatan setiap 30 menit. Pencatatan tersebut dilakukan dengan alat Automatic Water Level Logger Hobo U-30. Pengukuran debit aliran untuk membuat rating curve dan hidrograf aliran dilakukan sebanyak delapan kali dengan metode velocity area method. Selanjutnya, analisis komponen hidrograf banjir dan perhitungan MRC untuk menentukan derajat karstifikasi dilakukan pada hidrograf aliran yang terbentuk selama periode pengukuran.

Master Recession Curve (MRC) dan Derajat Karstifikasi Akuifer Karst

Berkembangnya komputasi digital menjadikan perhitungan MRC saat ini banyak dilakukan secara automatis. Posavec dkk (2006) menggunakan perangkat lunak Visual Basic untuk menghitung MRC dengan metode matcing strip secata automatis. Penelitian ini menghitung MRC dengan metode matching strip dengan bantuan perangkat lunak RC 4.0. Perangkat lunak ini tergolong user friendly dan mampu menghitung MRC secara automatis maupun semi automatis (Gregor dan Malik, 2010).

Pada penelitian ini, MRC dibangun menggunakan dua persamaan resesi, yaitu simple exponential (1) untuk tipe aliran laminar (diffuse flow) dan linier turbulent (2) untuk tipe aliran turbulen (conduit flow). Menurut Malik dan Vojtkova (2010), kejadian banjir dapat terdiri dari beberapa aliran laminar dan turbulen seperti yang disajikan pada Gambar 3. Selanjutnya, keberadaan tipe aliran laminar atau turbulen pada kondisi resesi digunakan untuk menentukan derajat karstifikasi (Malik, 2007). Derajat karstifikasi tersebut terdiri dari sepuluh kelas yang menunjukkan karst paling berkembang memiliki derajat tertinggi.

$$
\begin{gathered}
Q_{t}=Q_{0} e^{-\alpha t} \\
Q_{t}=Q_{0}(1-\beta t)
\end{gathered}
$$

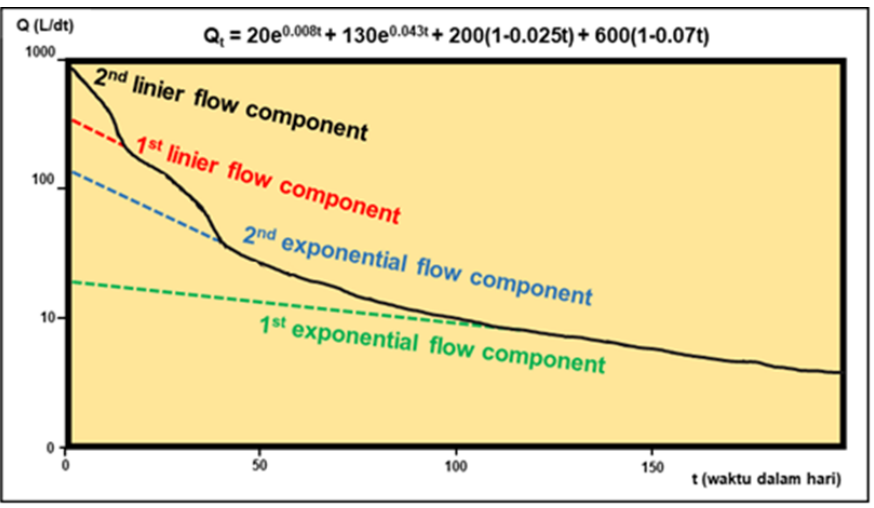

Gambar 3.Ilustrasi MRC dengan 2 tipe aliran exponensial dan linier (diadposi dari Malik dan Vojtkova, 2012) 
Karakteristik Hidrograf Banjir

Hidrograf banjir memiliki bentuk seperti lonceng yang terdiri dari beberapa komponen, yaitu waktu tunda $\left(\mathrm{T}_{\text {lag }}\right)$, debit puncak $\left(\mathrm{Q}_{\mathrm{p}}\right)$, dan waktu menuju aliran dasar $\left(\mathrm{T}_{\mathrm{b}}\right)$. $\mathrm{T}_{\mathrm{lag}}$ merupakan jarak waktu antara puncak kejadian hujan hingga debit puncak, $\mathrm{Q}_{\mathrm{p}}$ merupakan debit puncak kejadian banjir, dan $\mathrm{T}_{\mathrm{b}}$ merupakan jarak waktu antara $\mathrm{Q}_{\mathrm{p}}$ hingga aliran dasar tercapai kembali (Gambar 4). Hidrograf banjir dapat menjadi indikator dalam karakterisasi akuifer karst karena bentuk atau komponennya yang mencerminkan kondisi daerah tangkapan, besar kecilnya simpanan, dan cara pelepasan aliran (Adji dkk, 2016). Nurkholis dkk (2018) menggunakan hidrograf banjir untuk melakukan karakterisasi akuifer di Sistem Karst Gua Pindul. Penelitian ini menghitung $\mathrm{T}_{\mathrm{lag}}, \mathrm{Q}_{\mathrm{p}}$, dan $\mathrm{T}_{\mathrm{b}}$ pada setiap kejadian banjir yang terjadi di Mataair Mudal.

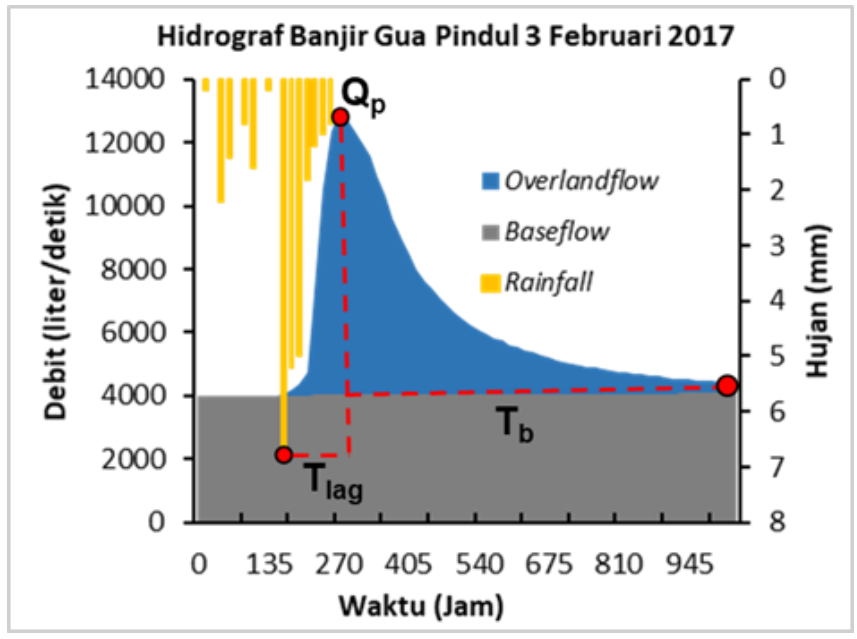

Gambar 4. Ilustrasi hidrograf banjir yang terdiri dari waktu tunda $\left(\mathrm{T}_{\text {lag }}\right)$, debit puncak $\left(\mathrm{Q}_{\mathrm{p}}\right)$, dan waktu menuju aliran dasar $\left(\mathrm{T}_{\mathrm{b}}\right)$ (diadposi dari Nurkholis dkk, 2018)

\section{HASIL DAN PEMBAHASAN}

Hidrograf Aliran dan Karakteristik Banjir Mataair Mudal

Hubungan antara debit aliran dan tinggi muka air hasil pencatatan selama periode pengukuran menghasilkan stage discharge rating curve seperti yang disajikan pada Gambar 5. Rating curve tersebut memiliki persamaan (3) dengan $\mathrm{R}^{2}$ bernilai 0,88 .

$$
Q=1756 T M A-406,64
$$

Di mana, $\mathrm{Q}=$ debit aliran (liter/detik)

TMA = tinggi muka air $(\mathrm{m})$

Selanjutnya, hidrograf aliran selama kurun waktu 7 November 2017 - 16 Mei 2018 disajikan pada Gambar 6. Dari Gambar 6 tampak bahwa musim penghujan yang dicirikan dengan adanya beberapa hidrograf banjir terjadi pada bulan November 2017 hingga Maret 2018, sedangkan musim kemarau mulai terjadi sejak bulan April 2018. Sementara itu, debit aliran dasar pada musim kemarau berkisar 400 liter/detik yang mengalami peningkatan menjadi sekitar 700 liter/detik pada musim penghujan.

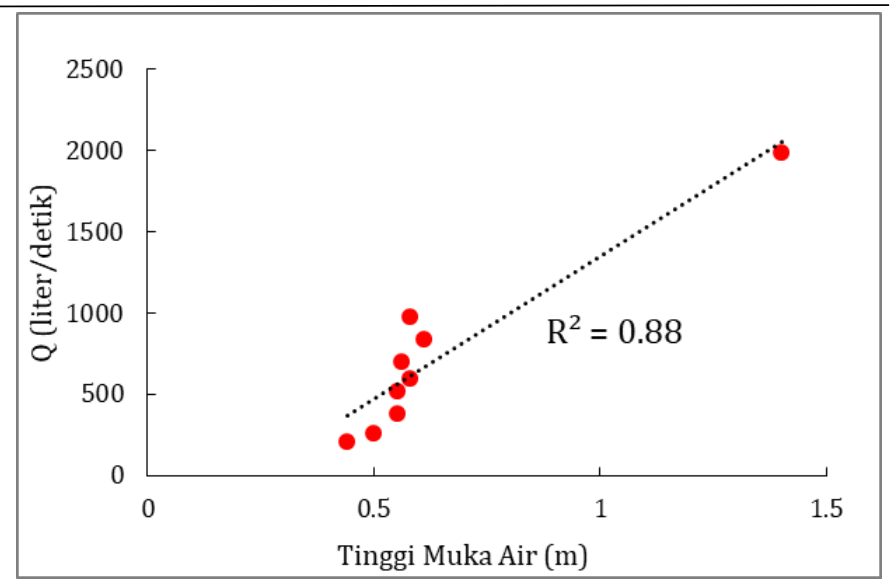

Gambar 5. Stage discharge rating curve Mataair Mudal

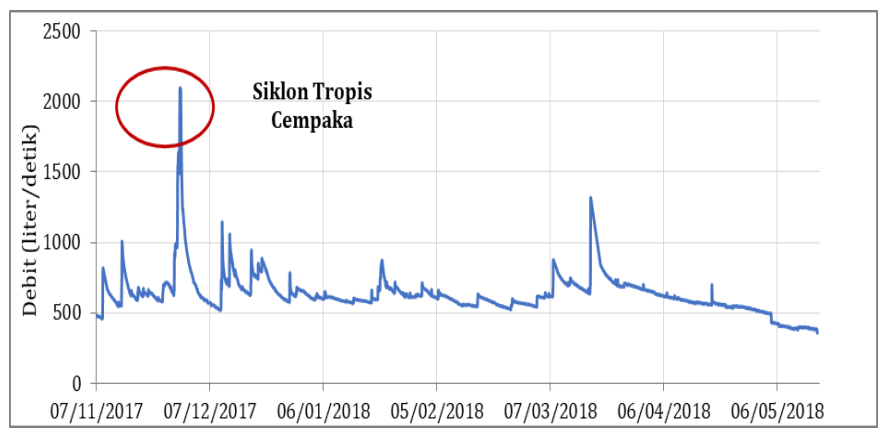

Gambar 6. Hidrograf aliran Mataair Mudal

Tabel 1. Karakteristik komponen hidrograf banjir di Mataair Mudal

\begin{tabular}{lrrr}
\hline Waktu & $\mathrm{T}_{\text {lag }}(\mathrm{jam})$ & $\mathrm{Q}_{\mathrm{p}}$ (liter/detik) & $\mathrm{T}_{\mathrm{b}}(\mathrm{jam})$ \\
\hline $11 / 08 / 2017$ & 1,75 & 819 & 28 \\
$13 / 11 / 2017$ & 3,75 & 1005 & 27 \\
$12 / 10 / 2017$ & 1,5 & 1141 & 16 \\
$12 / 12 / 2017$ & 2 & 1057 & 28 \\
$21 / 12 / 2017$ & 5 & 856 & 86 \\
$21 / 01 / 2018$ & 1,25 & 873 & 15 \\
$03 / 07 / 2018$ & 4 & 876 & 75 \\
$17 / 03 / 2018$ & 1 & 1317 & 71 \\
Minimum & 2 & 1332 & 30 \\
Maximum & 2,5 & 1795 & 40 \\
Rerata & 2,5 & 993 & 43 \\
\hline
\end{tabular}

Tabel 2. Perbandingan komponen hidrograf banjir di Mataair Mudal, Gua Pindul, Gua Gilap, dan Mataair Petoyan

\begin{tabular}{lrrrr}
\hline Karakteristik & \multicolumn{1}{c}{ Mudal } & Pindul & Gilap & Petoyan \\
\hline $\mathrm{T}_{\mathrm{lag}}($ jam $)$ & 2,5 & 2 & 3 & 6 \\
$\mathrm{Q}_{\mathrm{p}}($ liter/detik $)$ & 993 & 12.232 & 172 & 59 \\
$\mathrm{~T}_{\mathrm{b}}($ jam $)$ & 43 & 13,4 & 36 & 42 \\
\hline
\end{tabular}

Banjir yang terjadi pada tanggal 27 November 2017 merupakan kejadian ekstrim yang disebabkan oleh siklon tropis Cempaka. Oleh karena itu, kejadian tersebut tidak digunakan pada analisis penelitian ini. Debit puncak pada kejadian siklon tropis Cempaka mencapai sekitar 2000 liter/ detik. 
Analisis komponen hidrograf banjir dilakukan pada enam kejadian banjir, karena tidak semua kejadian banjir dapat dihitung komponen hidrografnya. Analisis komponen hidrograf banjir hanya dapat dilakukan pada hidrograf banjir yang memiliki puncak tunggal dan masa resesi yang terlihat jelas (Schulz, 1976). Tabel 1 menyajikan hasil perhitungan $T_{\text {lag, }} Q_{p}$, dan $T_{b}$ di Mataair Mudal, yang menunjukkan bahwa Mataair Mudal memiliki rerata nilai $\mathrm{T}_{\mathrm{p}}$ 2,5 jam, $\mathrm{Q}_{\mathrm{p}} 993$ liter/detik, dan $\mathrm{T}_{\mathrm{b}}$ 43jam.

Perbandingan perhitungan komponen hidrograf banjir di Mataair Mudal dengan beberapa matair karst pada beberapa lokasi lain disajikan pada Tabel 2. Gua Pindul merupakan outlet dari sistem karst yang telah berkembang dengan ciri diimbuh oleh sinking stream dan sistem perguaan (Nurkholis dkk, 2018). Gua Gilap merupakan hulu dari sistem karst Bribin yang memiliki dominasi retakan fissure (Haryono dkk, 2016). Petoyan merupakan mataair karst yang masih didominasi oleh retakan diffuse (Adji dan Bahtiar, 2016). Jika dibandingkan dengan lokasi-lokasi tersebut di atas, maka Mataair Mudal memiliki $\mathrm{Q}_{\mathrm{p}}$ terbesar kedua (setelah Gua Pindul) serta $\mathrm{T}_{\mathrm{lag}}$ yang cepat (hampir sama dengan yang dialami oleh Gua Pindul). Hal ini mencerminkan telah berkembangnya tipe retakan conduit pada sistem karst yang mengimbuh Mataair Mudal. Sementara itu, nilai $\mathrm{T}_{\mathrm{b}}$ Mataair Mudal memiliki nilai yang tergolong lambat (43 jam) yang hampir sama dengan Mataair Petoyan meskipun dengan $\mathrm{Q}_{\mathrm{p}}$ yang jauh lebih besar. Hal ini mencirikan akuifer karst yang mengimbuh Mataair Mudal masih baik dalam menyimpan airtanah pada retakanretakan yang berukuran kecil (diffuse flow).

\section{Master Recession Curve (MRC) Mataair Mudal}

MRC pada Mataair Mudal dibentuk dari 5 single recession curves (RC). Gambar 7 menunjukkan Mataair Mudal memiliki dua tipe resesi linier reservoir dan satu tipe resesi exponential. Tipe resesi exponential mencirikan adanya tipe aliran conduit yang dilepaskan oleh akuifer karst yang mengimbuh Mataair Mudal, sedangkan resesi linier pertama menunjukkan dimulainya pelepasan aliran diffuse. Sementara itu, resesi linier kedua dapat diidentikkan dengan mulai dilepaskannya aliran fissure. Menurut Atkinson (1985), beberapa akuifer karst juga memiliki tipe aliran fissure yang mengalir melalui rekahan berukuran intermediate.

MRC yang dibentuk dari beberapa RC merupakan gambaran dari karakteristik akuifer karst dalam melepaskan alirannya. Berdasarkan konsep tersebut, Mataair Mudal memiliki waktu pelepasan aliran conduit antara 0 hingga 5 jam; durasi pelepasan aliran fissure 5 - 40 jam; dan waktu pelepasan aliran dasar (diffuse) $\left(\mathrm{T}_{\mathrm{b}}\right.$ ) sekitar 40 jam (yang mendekati perhitungan $\mathrm{T}_{\mathrm{b}}$ pada komponen hidrograf banjir, yaitu 43 jam). Dalam hal ini, maka perhitungan $T_{b}$ menggunakan MRC mengonfirmasi perhitungan $T_{b}$ secara manual menggunakan parameter hidrograf banjir sebagaimana telah dijelaskan di atas.

\section{Derajat Kartifikasi (Perkembangan) Akuifer Karst di Mataair Mudal}

Mataair Mudal memiliki MRC seperti yang disajikan pada persamaan (4). Persamaan tersebut terdiri dari dua simple exponential (tipe resesi linear reservoir) dan satu persamaan simple linear turbulent (tipe resesi turbulent flow). Berdasarkan klasifikasi oleh Malik (2007), Mataair Mudal memiliki derajat karstifikasi 5,5 (complex discharge regime) dengan karakteristik masih mendominasinya retakan bertipe diffuse dan fissure dengan mulai adanya sedikit pengaruh dari jaringan conduit.

$Q_{t}=820 e^{-0.005 t}+130 e^{-0.12 t}+190(1-0.25 t)$

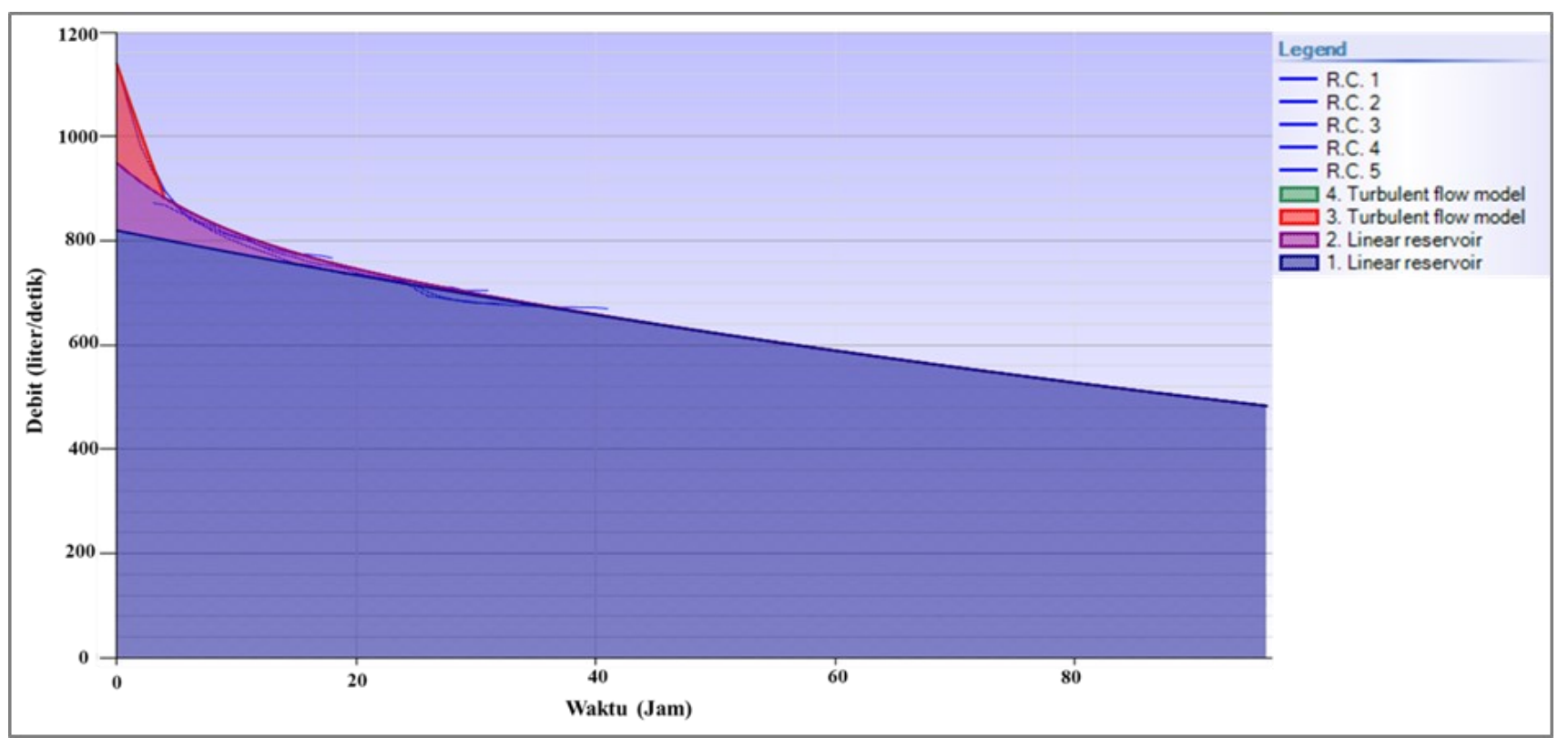

Gambar 7. Master Recession Curve (MRC)pada Mataair Mudal 
Complex discharge regime pada Mataair Mudal dibuktikan dengan adanya tipe aliran conduit, fissure, dan diffuse pada grafik MRC. Berkembangnya tipe pelorongan conduit dibuktikan dengan adanya sungai bawah tanah yang muncul sebagai Mataair Mudal (sungai resurgence) (Gambar 2). Selain itu, waktu menuju puncak banjir $\left(\mathrm{T}_{\mathrm{p}}\right)$ Mataair Mudal yang tergolong cepat (rerata 2,5 jam) juga mencerminkan adanya aliran conduit pada kejadian hujan (Tabel 1).

Masih dominannya aliran diffuse di Mataair Mudal mencerminkan akuifer karst yang mengimbuhnya masih baik dalam menyimpan airtanah. Hal ini ditunjukkan dengan nilai waktu menuju aliran dasar $\left(\mathrm{T}_{\mathrm{b}}\right)$ yang tergolong lambat (43 jam) (Tabel 1). Secara pengamatan di lapangan, debit aliran Mataair Mudal yang tidak pernah kering sepanjang musim menguatkan hal tersebut.

\section{KESIMPULAN}

Mataair Mudal memiliki rerata debit aliran dasar 400 liter/detik pada musim kemarau dan 700 liter/detik pada musim penghujan. Perhitungan derajat karstifikasi menunjukkan bahwa Mataair Mudal memiliki derajat karstifikasi 5,5 (complex discharge regime). Kekompleksan tersebut dikonfirmasi dengan adanya tipe aliran conduit (durasi pelepasan $0-5$ jam), fissure (durasi pelepasan $5-43$ jam), dan diffuse (durasi pelepasan sekitar 40 jam) pada perhitungan MRC. Sementara itu, analisis komponen hidrograf banjir menguatkan hasil perhitungan derajat karstifikasi pada lokasi kajian. Waktu menuju puncak banjir $\left(\mathrm{T}_{\mathrm{lag}}\right)$ yang tergolong cepat $(2,5 \mathrm{jam})$ menunjukkan adanya aliran conduit pada kejadian hujan. Perhitungan waktu menuju aliran dasar $\left(\mathrm{T}_{\mathrm{b}}\right)$ secara manual menggunakan hidrograf banjir memiliki nilai yang hampir sama dengan MRC, yaitu sekitar 40 jam. Hal tersebut menunjukkan bahwa akuifer karst yang mengimbuh Mataair Mudal masih baik dalam menyimpan airtanah.

\section{UCAPAN TERIMA KASIH}

Penelitian ini didanai oleh skema Hibah Penelitian Dosen Fakultas Geografi UGM dari Dana Bantuan Pendanaan Perguruan Tinggi Negeri Berbadan Hukum (BPPTN-BH) Tahun Anggaran 2018. Penulis juga mengucapkan terimakasih sebesar-besarnya kepada Bapak Kepala Desa Jatimulyo, Kec. Girimulyo, Kab. Kulon Progo, DIY yang telah memberikan fasilitas pengawasan sehingga penelitian ini dapat berjalan dengan lancar.

\section{DAFTAR PUSTAKA}

Adji, T.N., Bahtiar, I.Y. (2016). Rainfall-discharge relationship and karst flow components analysis for karst aquifer characterization in Petoyan Spring, Java, Indonesia. Environmental Earth Sciences, 75, 735.

Adji, T.N., Haryono, E., Fatchurohman, H., dan Oktama, R. (2017a). Spatial and temporal hydrochemistry variations of karst water in Gunung Sewu, Java Indonesia. Environmental Earth Sciences, 76, 709.

Adji, T.N., Haryono, E., Mujib, A., Fatchurohman, H., dan Bahtiar, I. (2017b). Assessment of aquifer karstification degree in some karst sites on Java Island, Indonesia. Carbonates and Evaporites, 32, $1-14$.

Adji, T.N., Haryono, E., Fatchurrohman, H., dan Oktama, R.(2016). Diffuse flow characteristics and their relation to hydrochemistry conditions in the Petoyan Spring, Gunungsewu Karst, Java, Indonesia. Geosciences Journal, 20, 381-390.

Arnold, J.G., Allen, P.M., Muttiah, R., dan Bernhardt, G.(1995). Automated base flow separation and recession analysis techniques. Groundwater, 33, $1010-1018$.

Atkinson, T.C. (1985). Present and future directions in karst hydrogeology. Ann. Soc. Geoi. Belgique, 108, 293 - 296.

Barnes, B.S. (1939). The structure of discharge-recession curves. Eos Trans. AGU, 20, 721-725.

Berhail, S., Ouerdachi, L., dan Boutaghane, H. (2012). The use of the recession index as indicator for components of flow. Energy Procedia, 18, 741 - 750.

Bonacci, O.(1993). Karst springs hydrograph as indicators of karst aquifers. Hydrologies Sciences Journal-des Sciences Hydrologiques, 38, 2.

Fatchrurohman, H. (2017). Characterization and management of karst drainage system based on hydrograph analysis in Gunung Sewu Karst Area Master. Tesis di Fakultas Geografi, Universitas Gadjah Mada, Indonesia.

Fatchrurohman, H.,Adji, T.N., Haryono, E., dan Wijayanti, P. (2018). Baseflow index assessment and master recession curve analysis for karst water management in Kakap Spring, Gunung Sewu. IOP Conf. Series: Earth and Environmental Science, 148.

Ford, D., Williams, P. (1989). Karst Hydrology and Geomorphology. West Sussex: John Wiley \& Sons Ltd.

Gregor, M.,dan Malik, P.(2010). RC 4.0 User's Manual Hydro Office Sofware for Water Science. link: https:// hydrooffice.org/Downloads?Items=Manual

Haryono, E., Danardono., Mulatsih, S., Putro, S.T.,dan Adji, T.N. (2016) The Nature of Carbon Flux in Gunungsewu Karst, Java-Indonesia. Acta Carsologica, 45, 173-185.

Jeannin, P.Y.,\& Sauter, M.(1998). Analysis of karst hydrodynamic behaviour using global approaches: a review Bulletin d'Hydrogéologie. Neuchatel, 16, 31-48.

Kullman, E. (2000). Nove metodicke pristupy k rieseniu ochrany a ochrannych pasiem zdrojov podzemnych vod $\mathrm{v}$ horninovych prostrediach a krasovopuklinovou a puklinovou priepustnostou. Podzemna voda, $6,31-41$.

Kurniawan, I.A., Adji, T.N., Nurkholis, A., Haryono, E., Fatoni, H., Waskito, W.A., Cahyadi, A., Agniy, R.F. (2019) Karst aquifer response by time series analysis applications in Jonggrangan Karst, Java Island, Indonesia. Environmental Earth Science, 78, 379.

DOI: https://doi.org/10.1007/s12665-019-8386-x

Langbein, W.B. (1938). Some channel storage studies and their application to the determination of infiltration. Eos Trans. AGU, 19, 435 - 447.

Maillet, E. (1905) Essais d'Hydr aulique Souterraine et Fluvi ale.Hermann Paris, 218.

Malik, P. (2007) Assessment of regional karstification degree and groundwater sensitivity to pollution using hydrograph analysis in the Velka Fatra Mts., Slovakia. Environ. Geol., $51,707-711$

Malik, P., Vojtkova, S. (2012). Use of recession-curve analysis for estimation of karstification degree and its application in assessing overflow/underflow conditions in closely spaced karstic springs. Environmental Earth Sciences, 65, 2245 2257.

Mujib, M.A., (2015). Analisis karakteristik dan tingkat karstifikasi akuifer karst di sistem Mataair Ngerong, Kecamatan 
Rengel, Kabupaten Tuban Master.Tesis di Fakultas Geografi, Universitas Gadjah Mada, Indonesia.

Nathan, R.J., McMahon, T.A. (1990). Evaluation of automated techniques for baseflow and recession analyses. Water Resour. Res, 7, 1465-1473.

Nurkholis, A., Adji, T.N., Haryono, E., Cahyadi, A.,dan Agniy, R.F. (2017). Spatial and temporal variation of flow characteristics to aquifer characterizations of Pindul Karst System, Gunungkidul Regency. Proceeding of 2nd annual conference of groundwater expert association (PIT-PAAI), 13-15 September 2017, Yogyakarta. (doi: http:// doi.org/10.17605/OSF.IO/87D2K )

Nurkholis, A., Cahyadi, A., dan Agniy, R.F. (2018) Spatial and temporal flood characterization of Pindul Karst System, Gunungkidul Regency. IOP Conf. Series: Earth and Environmental Science, 145.

Nurkholis, A., Adji, T.N., Haryono, E., Cahyadi, A., Suprayogi. (2019). Time series analysis application for karst aquifer characterization in Pindul Cave Karst System, Indonesia. Acta Carcologica, 48/1, 69-84. DOI: https:// doi.org/10.3986/ac.v48i1.6745
Posavec, K., Bacani, A.,dam Nakic, Z.(2006). A visual basic spreadsheet macro for recession curve analysis.Ground Water, 44, $764-767$.

Schulz, E.F., (1976). Problems in Applied Hydrology. Water Resources Publication, Colorado

Snyder, F.F.(1939). A concept of runoff-phenomena. Eos Trans. AGU, 20, 25 - 738.

Sari, A.M. (2017). Evaluasi pelaksanaan corporate social responsibility PT. PLN (Persero) area Yogyakarta di Ekowisata Taman Sungai Mudal. Skripsi di Fakultas Ilmu Politik dan Sosial, Universitas Muhammadiyah Yogyakarta, Indonesia.

Tallaksen, L.M. (1995). A review of baseflow analysis. Journal of Hydrology, 165, 349-370. 